\section{Fungi for Food}

THE larger fungi contain appreciable amounts of protein, carbohydrates and vitamins suitable for human nutrition, but their unique flavours, compounded from a plethora of little-known substances, make an even greater contribution to gastronomic variety. Dr. J. Ramsbottom is trying to stimulate interest in a wider use of our native fungi, and in a recent short paper (J. Roy. Hort, Soc., 68, Pt. 10 ; Oct. 1943) describes fourteen species which might supplement the mushroom in our diet. The chanterelle (Cantharellus cibarius), blewits (Tricholoma personatum and the related $T$. nudum) and the morel (Morchella esculenta) may already be known to some connoisseurs, but the others are no less tasty. The great need appears to be for inspiration in methods of cooking. Dr. Ramsbottom has made a start in this direction, but much yet remains to be accomplished. The common Hygrophorus pratensis, for example, though palatable in the raw state, can be converted into a tough leathery mass by incorrect culinary preparation. All the species mentioned in Dr. Ramsbottom's paper, however, can be trusted to yield their flavour, and stimulate the palate, even with ordinary methods of cooking.

\section{Poisonous Gases in the Exhaust of Diesel Engines}

Dr. Enrique Castellano has an article on this subject in Publicaciones de la Facultad de Ciencias Fisicomatematicas, Universidad Nacional de la Plata (June 1943), in which he gives a full account of his experiments to discover if pernicious effects are produced in the driver's cabin by the fumes from the exhaust. A description is given of the methods adopted for determining the amount of each of the gases ejected, and the results are summarized at the end of the paper. Comparing the figures with those for the concentration dangerous to human life for each gas, it is interesting to notice that there is a large margin in the concentration of carbon monoxide -a gas which is generally believed to be extremely dangerous in the fumes from the exhaust.

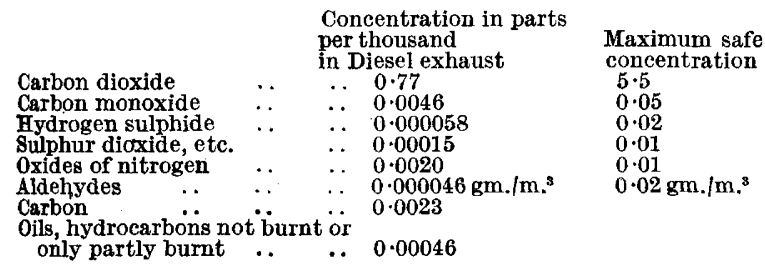

From these figures it appears that the concentration of gases in the cabin is far below that which is usually considered detrimental to life. In the case of the hydrocarbons and carbon, it is impossible to draw any definite conclusions, because no figures are available regarding the concentrations which are considered dangerous to human life.

\section{Portuguese Navigators}

ReFerRING to the article in NATURE of November 27 on "Anglo-Portuguese Scientific Relations", Mr. Arthur J. Hughes, of Messrs. Henry Hughes and Son, Ltd., nautical and aeronautical instrument manufacturers, remarks that "the work of Prince Henry the Navigator is still being gloriously continued in Portugal. Perhaps two of the greatest navigators of the air were the late Comdr. Cabral and Admiral
Coutinho, of the Portuguese Navy, who crossed the Atlantic in 1922, on the way making a brilliant landing at the Azores by close and accurate navigation. There is in Brazil to-day a great descendant of the Portuguese, Capt. Radler Acquino, who is an acknowledged expert on all methods of modern navigation. He has just published a new book of tables in Portuguese, which would delight the heart of Henry the Navigator by their simplicity. There are also tables in navigation by distinguished Portuguese navigators, Newton and Pinto, in 1930 and 1933, and there is a very close scientific connexion in nautical science and hydrography between the Portuguese and British Navies."

\section{Newton's Verses}

NEwTon's habit of transcribing passages from the writings of others has misled some writers into regarding him as something of an alchemist. Prof. E. N. da C. Andrade now concludes (Proc. Phys. Soc., 55, 426 ; 1943) that the same habit has misled those authors who have regarded Newton as something of a poet. When he was a boy, Newton apparently drew a picture of Charles I and wrote some verses underneath. Mrs. Vincent of Grantham repeated them by memory to Stukeley, who adds, "She fancyed, and aver'd it that he composed them himself. I rather suppose he copyed the print prefixed to the Eikon basilice". Prof. Andrade reproduces the verses from the "Eikon basilice". Comparison of the two versions suggests that Newton omitted the last six lines in transcribing the verses, and that Mrs. Vincent may have recollected imperfectly what he wrote. A recent biographer wrote: "These are very good verses in the fashion of the day to be written by a boy of his age". Prof. Andrade concludes : "The Eikon basilice verses, though poor and conventional, show some slight feeling for poetry. I do not think that Newton can ever have written anything even as good as this."

\section{Comet Peltier-Kellaway}

Comet Pectier-Kellaway was discovered by Peltier on December 17 and independently by G. F. Kellaway, West Coker, Somerset, on December 19. Its magnitude at the time of discovery was about 6 . It made its closest approach to the sun on January 19 and is becoming fainter.

\section{Announcements}

Prof. Niels Bohr, professor of theoretical physics, University of Copenhagen, has been elected a member of the Athenæum under Rule II of the club, which permits the "annual election by the committee of a certain number of persons of distinguished eminence in science, literature, or the arts, or for their public services".

DR. R. E. Mortimer WheELER, director of the Society of Antiquaries and keeper of the London Museum, has been appointed director-general of archæology in India.

IT is announced that the ship-building industry in Great Britain, after consultation with the Department of Scientific and Industrial Research and the Admiralty, has decided to establish a British Shipbuilding Research Association, to develop all branches of research associated with ship-building, marine engineering and ship repairing. 